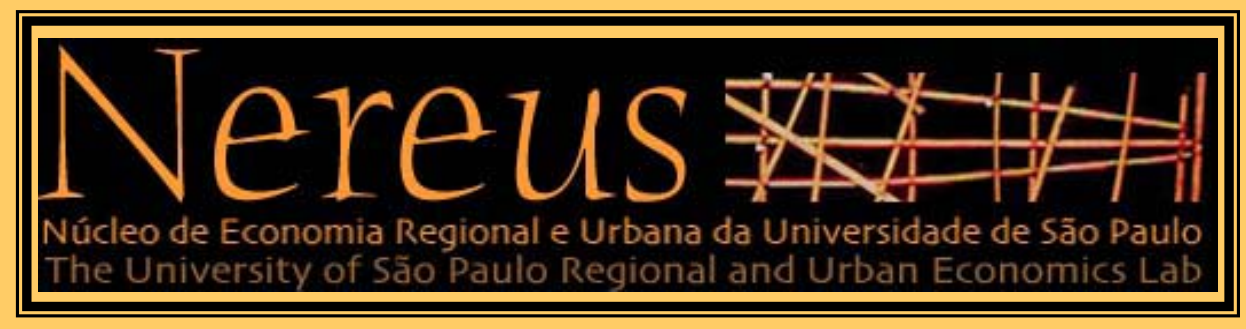

\title{
COMMODITY PRICE CHANGES AND THEIR IMPACTS ON POVERTY IN DEVELOPING COUNTRIES: THE BRAZILIAN CASE
}

\author{
Carlos R. Azzoni \\ Joaquim J.M. Guilhoto \\ Eduardo A. Haddad \\ Fernando G. Silveira \\ Tatiane Menezes \\ Marcos M. Hasegawa \\ TD Nereus 02-2005
}

São Paulo 2005 


\title{
Commodity Price Changes and Their Impacts on Poverty in Developing Countries: the Brazilian Case
}

\author{
Carlos R. Azzoni \\ FEA-USP \\ Av. Prof. Luciano Gualberto, 908 - São Paulo - SP 05508-900 \\ E-mail cazzoni@usp.br \\ Joaquim J.M. Guilhoto \\ FEA - USP \\ Av. Prof. Luciano Gualberto, 908 - São Paulo - SP 05508-900 \\ E-mail guilhoto@usp.br
}

\section{Eduardo A. Haddad}

FEA - USP

Av. Prof. Luciano Gualberto, 908 - São Paulo - SP 05508-900

E-mail ehaddad@usp.br

\section{Fernando G. Silveira}

IPEA

Av. Prof. Luciano Gualberto, 908 - São Paulo - SP 05508-900

E-mail gaiger@ipea.gov.br

\section{Tatiane Menezes}

FIPE

Av. Prof. Luciano Gualberto, 908 - São Paulo - SP 05508-900

E-mail menezess@usp.br

\section{Marcos M. Hasegawa}

Universidad Catolica del Norte - UCN

Avenida Angamos 0610 - casilla 1280 - Antofagasta - Chile

E-mail hasegawa@ucn.cl

\section{Comércio Internacional}

Apresentação com presidente da sessão e presença de um debatedor 


\title{
Commodity Price Changes and Their Impacts on Poverty in Developing Countries: the Brazilian Case
}

\begin{abstract}
The objective of the paper is to provide an estimative of the impacts that changes in international prices of agricultural commodities will have on income distribution and poverty in Brazil. To do so, a Social Accounting Matrix is constructed and applied, using a Leontief-Miyazawa type model framework. The SAM is defined for 40 products, being 17 raw agricultural products, 15 agricultural processed products, 3 industrial agricultural inputs, 2 other industrial products, trade, transport, and services. Households are allocated to 10 groups, being 6 agricultural (4 types of family farmers, commercial farmers, and agricultural labor), and 4 urban (income quartiles). Demand elasticities (price and income) for the products defined in the SAM are considered, as well as limitations on the supply of agricultural inputs. The knowledge of the possible impacts of changes in international commodity prices on income distribution and poverty is very important for policy design within developing countries. Given the estimated impacts on different groups of producers, different sorts of cushioning policies can be designed.
\end{abstract}

KEY-WORDS: Poverty, Brazil, Agriculture, Trade Liberalization, Social Accounting Matrix.

PALAVRAS-CHAVE: Pobreza, Brasil, Liberalização de Comércio, Agricultura, Matriz de Contabilidade Social. 


\section{Commodity Price Changes and Their Impacts on Poverty in Developing Countries: the Brazilian Case}

\section{Introduction}

Producers and households in developing countries are affected by the prices of products involved in international transactions. The impacts of agricultural policy and structural reforms leading to changes in international prices of goods and services are expected to be differentiated across households and producers, depending on how they are involved in the circular flow of goods and services within the country of residence. As such, it might be expected that these reforms will affect income distribution and poverty levels within those countries. Considering the supply side, units producing commodities facing price increases in the international markets will benefit, since their product will become more valuable; those using imported inputs whose prices increased as a result of the structural reforms will lose. As for households, those working in sectors with increased international prices could experience income gains, and those working in other sectors could rest unaffected in terms of income. However, since some prices would rise, households not working for gaining sectors could suffer a decrease in real income. A general price increase could also result, thus affecting all sorts of households.

Therefore, structural reforms that can change international prices are expected to produce important changes in income distribution in all countries involved in international trade. Since the impacts will vary according to the role played by different agents in the production and distribution of national income, it is important to produce a detailed analysis of such impacts. The objective of the paper is to provide an estimate the impacts of changes in international prices of agricultural commodities on income distribution and poverty in Brazil, considering not only the first round (direct) effects but also their spillovers (indirect effects) across the circular flow of income. The introduction of the second and higher round effects is important, for the initial effects could either be mitigated or empowered by the indirect effects. The knowledge of such compounded effects is important in the design of alternative policies for cushioning the measured adverse impacts of reforms on poor people. It is possible that an increase in the price of a very important export product of a country does not necessarily benefit all households equally. As a matter of fact, some may be badly hurt, if the prices of products with high participation in their consumption basket increased as a result of the second and higher order effects in the national economy, and if they do not work in sectors benefited by the initial price increase.

The paper is organized in 4 sections, including this introduction. The next section deals with the details of the model constructed in this study. Examples of how the model can be used to estimate distributive impacts of price shocks are presented in section 3 . Finally, in the last section the concluding remarks are presented. 


\section{The Model}

The goal of this section is to describe the various relationships embedded in the model. Its solution considers reactions of consumers to price and income changes, and reactions of producers to input price changes. It does not include, however, substitution effects between products and sectors. It is structured in five stages, as described below. The sum of the results calculated in these stages, partially considering the reactions of agents to price and quantity stimuli, comes close to a full general equilibrium model. In section 3, the results of the simulations using this SAM-based model are compared, in aggregate terms (global GDP, employment, price indexes, etc.) to a general equilibrium model. It will be shown that the disaggregated results provided by the model estimated in this study are compatible, at the aggregate level, with the ones resulting from the CGE model. On the other hand, the model presented here provides details on the impacts across farm types that is impossible to achieve within that CGE model.

\subsection{Model solution mechanics}

As a result of structural reforms in international trade, prices of commodities exported by the Brazilian economy are expected to change. It is expected that the international supply curve of protected commodities will shift upwards, leading to increases in international prices, as portrayed in Figure 2.1 below.

Figure 2.1 - Expected effects in the World Market

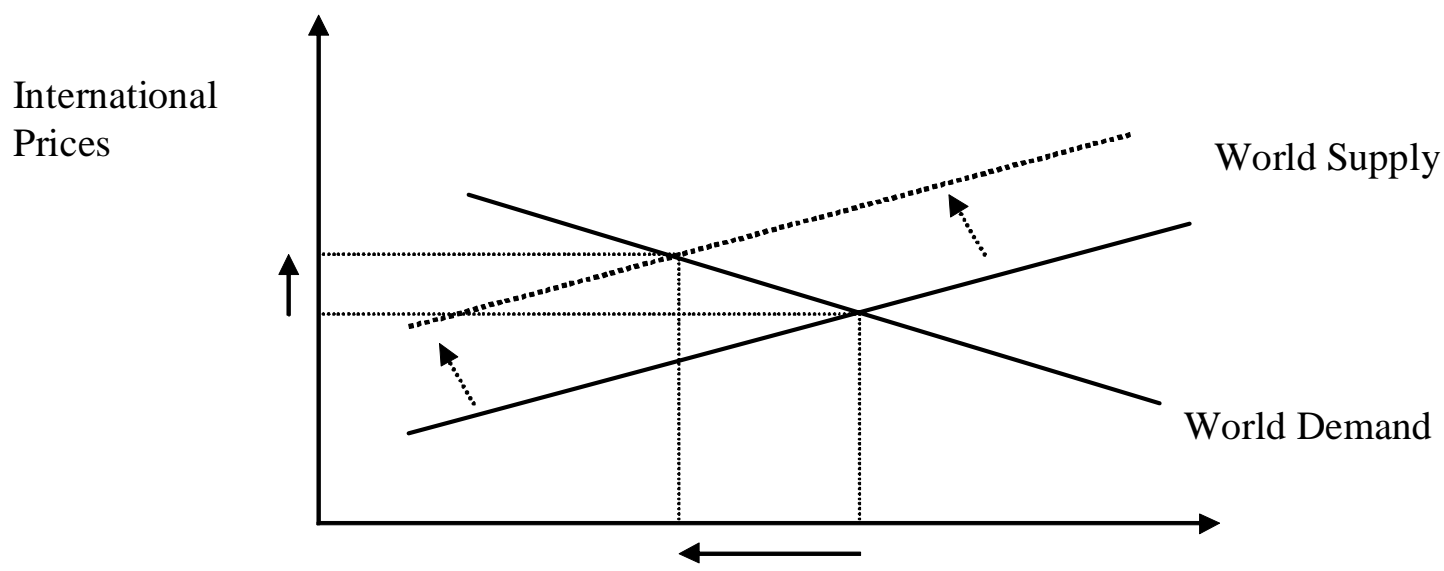

Volume traded

Some countries will be negatively affected by the changes, some countries positively. It is expected that the demand for Brazilian exports will increase, as portrayed in Figure 2.2 below. The effects on domestic prices will depend on the elasticity of domestic supply. In the case of a flat domestic supply curve, such as $S_{1}$, there will be no increase in the domestic price of the commodity, and thus no reduction in domestic 
consumption, and total production will increase by the amount of exports (arrow $\boldsymbol{b}$ in the figure). In the most probable case of some price transmission to the domestic market, such as in the case of a positive slope supply curve such as $S_{2}$, the domestic price is expected to increase (arrow c in the figure), leading to a reduction in the domestic consumption. Thus, the final increase in production will not be the full amount of exports, as before, but a smaller amount (arrow $\boldsymbol{a}$ in the figure). It will be equal to the increased amount of exports, less the decreased amount of domestic consumption (assuming this domestic price increase will not affect the country's competitiveness in the international market).

Figure 2.2 - Effects of a positive slopped domestic supply

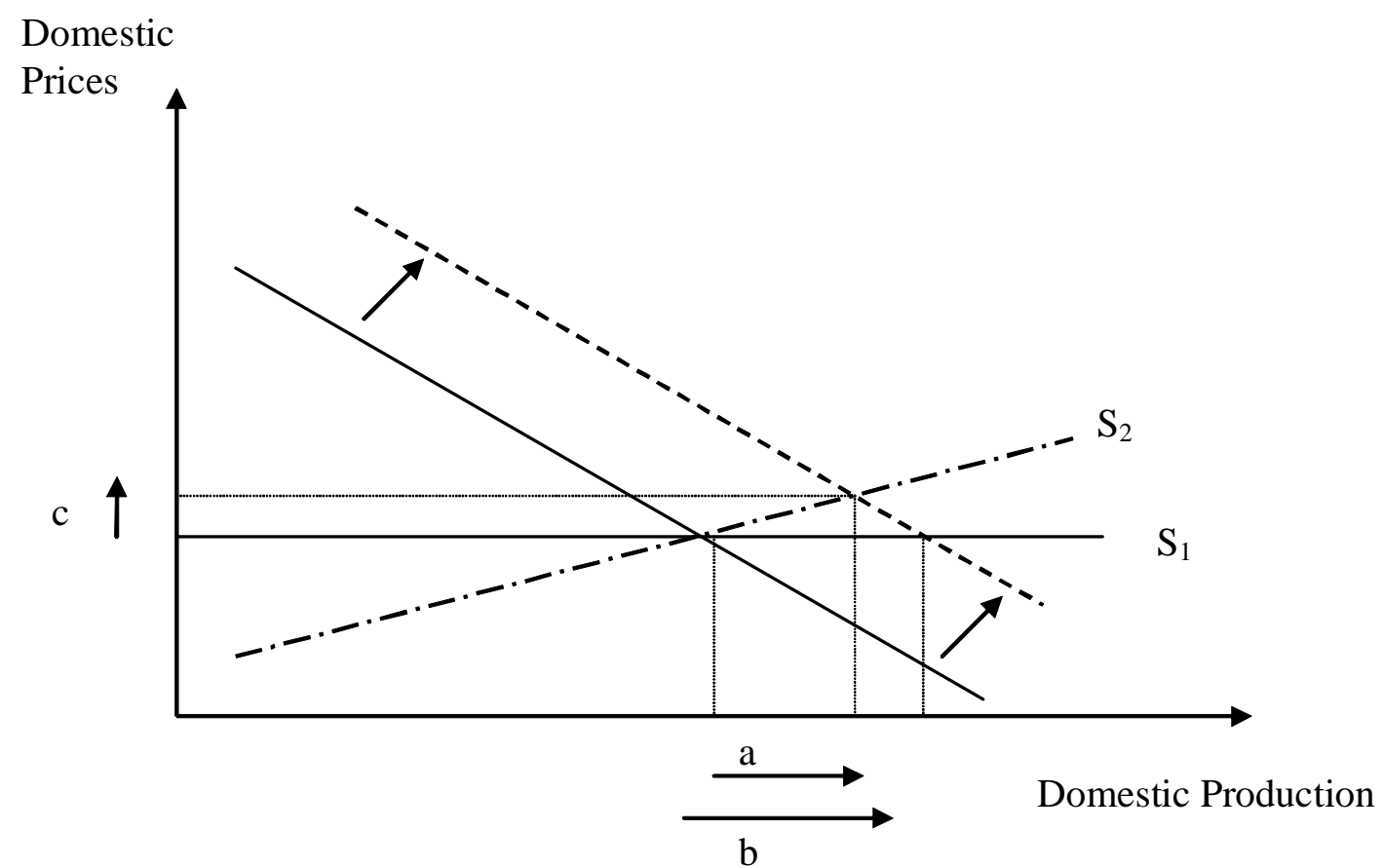

In order to estimate the impacts of this chain of events, the first stage of the model estimation simulates a situation in which the supply curve is such as $S_{1}$, that is, the whole increase in export volume is used to shock the model, ignoring any price increases. No restriction is imposed on the supply of inputs either. In other words, this stage simulates an increase in exported quantities at the previous price level. The results of this stage indicate the upper bound effect on national production, admitting that the additional production does not cause any price effect on the domestic market. Additional exports will be added to the previous production, imposing direct, indirect and induced effects on the system.

The price transmission from international to domestic prices considered is the one obtained from the resulting scenarios from OECD, i.e., results from the GTAP model. These estimates present expected international price changes as well as domestic price changes. This domestic price change for a product is supposed to spread to all prices in the 
economy through a Leontief-type price transmission mechanism. For example, an increase in the domestic price of soybeans will affect in the first place the prices of all sectors utilizing this product as an input, at fixed coefficients. In later stages, all prices will be affected in some way through the indirect effects generated by the original price increases.

The estimated domestic price changes will increase or decrease the production value of the specific product, depending on the price-elasticity of that product's demand. For a product with price-inelastic demand, which is the case of almost all food products, a domestic price increase will result in increased production value and income for that activity. In order to keep total income constant in the system, this extra income is transferred from all other sectors in the economy, whose incomes will fall proportionately to their participation in total production. Considering these changed incomes and the price changes, nominal and real income changes are calculated. Using estimated incomeelasticities, the income changes will be transformed into production value changes, adding another element to the estimation. At this stage, still no factor supply restriction is imposed, that is, a flat supply curve is supposed.

So far two results have been obtained. The first indicates the maximum effect of increased exports without any restriction on the supply side of the economy. Price effects have been introduced in the second stage, indicating the negative impacts on economic activity of the estimated price increases. In the third stage these results are just summed-up, to come up to the net results, still ignoring input supply restrictions.

Increased production of goods means increased use of inputs. If goods are produced with flat cost curves, there would be no effect on prices from the supply side; if production faces positive sloped cost curves, some supply reactions are to be expected. A way to consider this effect is to estimate product supply elasticities and include these factors in the estimation of the impacts. However, data limitations made it impossible to do it this way. The alternative used was to estimate the expected increases in input prices as a consequence of increased production, and to spread these price increases to the economy with a Leontief-type price transmission mechanism. The same chain of income and price changes described in the second stage is estimated.

As a matter of fact, the estimated model is not exactly as portrayed in Figure 2.2, but the one displayed in Figure 2.3 below, which reproduces the demands for Brazilian goods, and the flat domestic supply curve $S_{1}$ from Figure 2.2. As input prices rise, production costs go up in all sectors using these inputs, and the flat domestic supply curve moves upward, to $S_{3}$. This shift in supply affects the quantity transactioned in the same way as the reactions of producers in the upward slopped supply curve displayed in Figure 2.2, but the quantitative effects might be different. Thus, although the choice of this methodology to introduce domestic supply responses was determined by data restrictions alone, the input supply limitations introduced via the Leontief-type price transmission mechanism partially takes care of the problem. Off course, the two alternatives most probably will lead to different quantitative results, but the direction of change is the same.

Finally, the fifth stage just consolidates the upper-bound effect of the first stage, the influence of price transmission, and the influence of input limitations, coming up with the net effects on the national economy. Figure 2.4 summarizes the mechanics of the model solution. 
Figure 2.3 - Effects on the domestic market with a Leontief-type price transmission mechanism

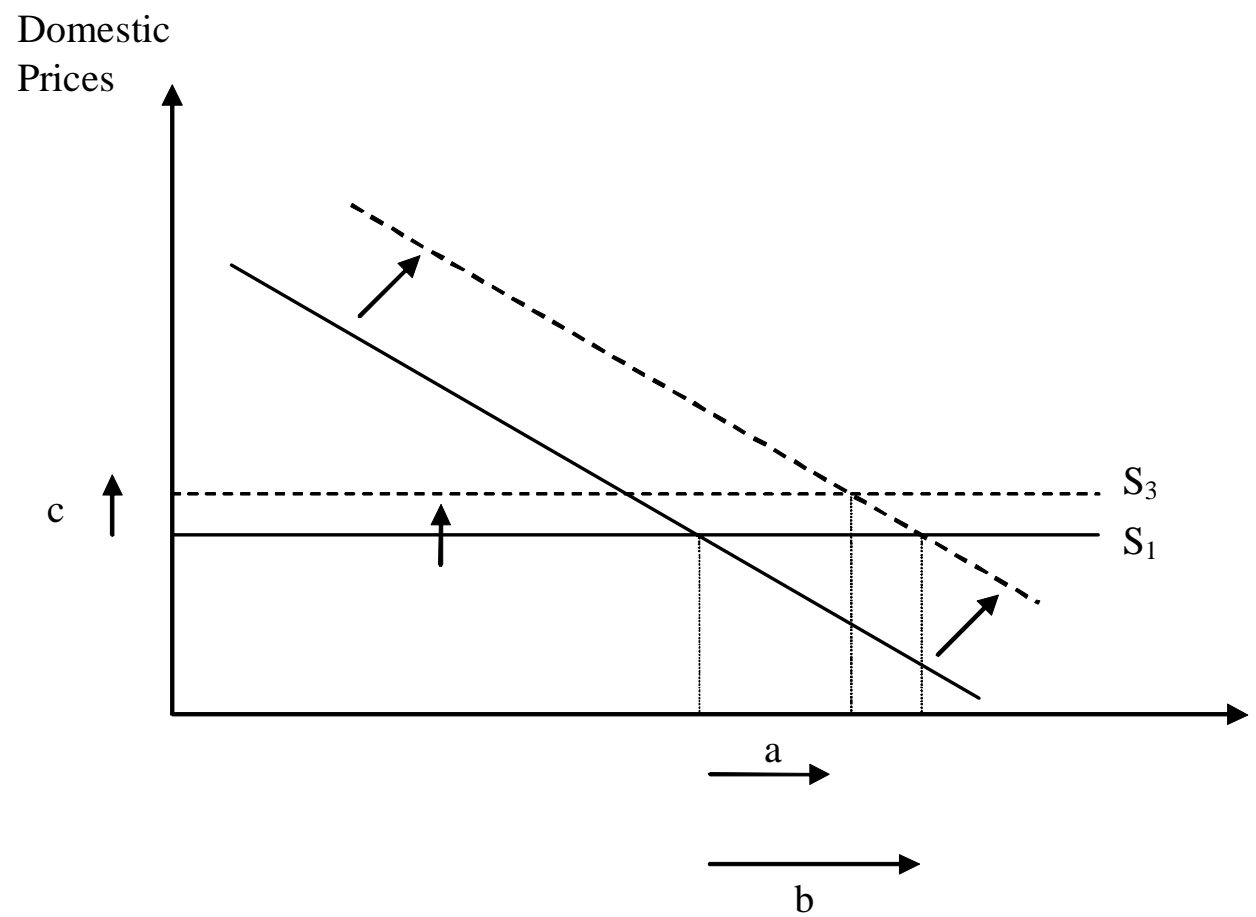


Figure 2.4 - Model solution schematics

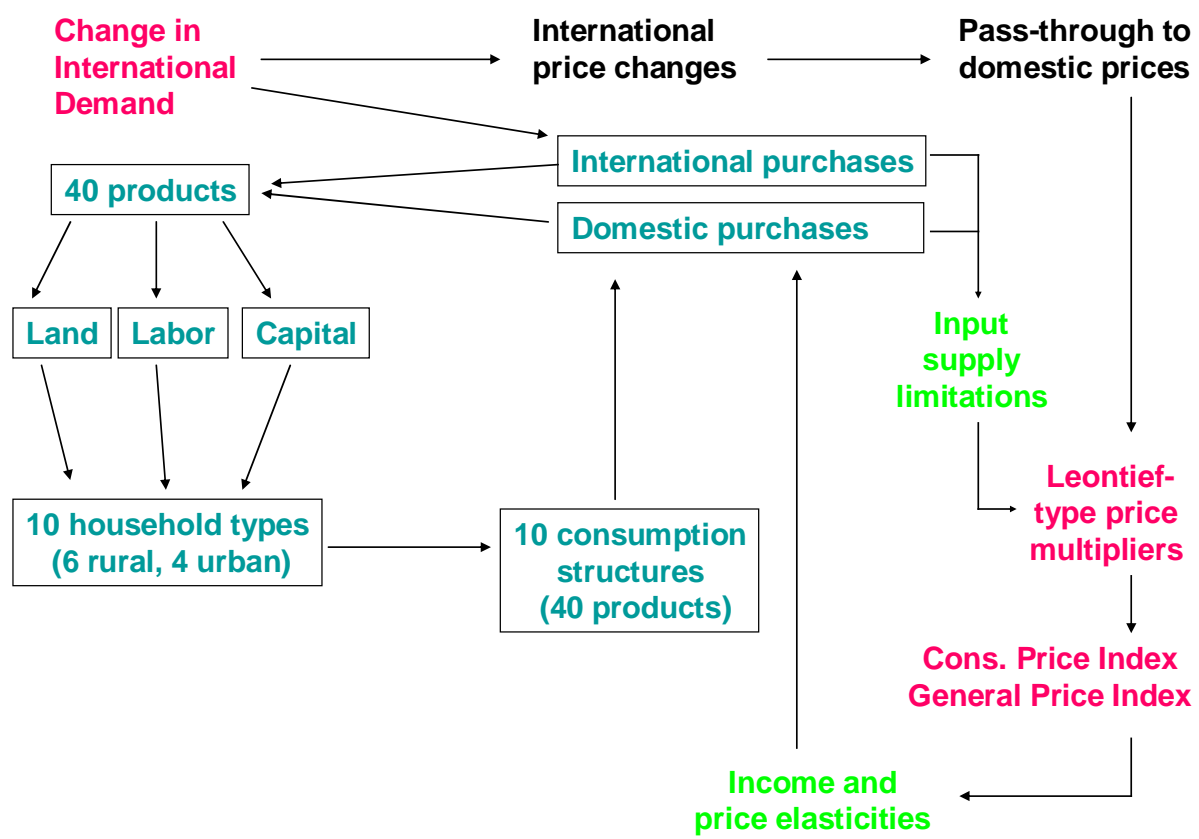

\subsection{Data Sources}

The SAM constructed and used in the model presented here is for the year of 1999 and is defined for 40 products, being 17 raw agricultural products, 15 agricultural processed products, 3 industrial agricultural inputs, 2 other industrial products, trade, transport, and services.

Table 2.1 presents more details on the importance of products. It can be seen that non agriculture-related products account for only $74.62 \%$ of total national production, in spite of the fact that Brazil is a major world producer of several products. In this table, trade and transportation activities are included in the group of agriculture-related activities. This is of course an overestimation, indicating that the share of agriculture-related sectors would be even smaller ${ }^{1}$. Agricultural products per se account for only $6.6 \%$, and food processing industries for $8.2 \%$. Each of these is less important, quantitatively, than distribution products (with 8.7\%). This reflects the fact that the Brazilian economy is large and diversified, and that urban activities are by far the most important.

\footnotetext{
${ }^{1}$ The share of agribusiness activities in Brazilian GDP in 2003 was 30.81\%, reflecting the growth in these activities after 1999, clearly well above other sectors in the Brazilian economy. For more details, see (http://www.cepea.esalq.usp.br/pib/other/pib_agronegocio_1994_03.xls).
} 
Table 2.1 - Importance of different products

\begin{tabular}{|c|c|c|}
\hline & $\begin{array}{c}\text { Production Value } \\
\text { (US } \$ 1,000)\end{array}$ & $\%$ \\
\hline Raw agricultural products & & $6.61 \%$ \\
\hline Coffee & $3,776,279$ & $0.40 \%$ \\
\hline Sugar Cane & $3,042,287$ & $0.32 \%$ \\
\hline Rice & $2,281,101$ & $0.24 \%$ \\
\hline Wheat & 277,731 & $0.03 \%$ \\
\hline Soybean & $4,302,112$ & $0.45 \%$ \\
\hline Corn & $2,811,213$ & $0.30 \%$ \\
\hline Beans & $1,003,527$ & $0.11 \%$ \\
\hline Cassava & $1,292,612$ & $0.14 \%$ \\
\hline Orange & 838,206 & $0.09 \%$ \\
\hline Other Fruits and vegetables & $2,428,879$ & $0.26 \%$ \\
\hline Cotton & 539,715 & $0.06 \%$ \\
\hline Other Crops & $12,317,972$ & $1.30 \%$ \\
\hline Poultry and egg production & $3,336,100$ & $0.35 \%$ \\
\hline Cattle ranching and farming & $7,090,160$ & $0.75 \%$ \\
\hline Hog and pig farming & $2,063,300$ & $0.22 \%$ \\
\hline Milk farming & $3,691,624$ & $0.39 \%$ \\
\hline Other animal production & $11,587,790$ & $1.22 \%$ \\
\hline Agricultural inputs & & $0.85 \%$ \\
\hline Tractors & $1,097,795$ & $0.12 \%$ \\
\hline Fertilizers & $4,497,500$ & $0.47 \%$ \\
\hline Agricultural defensives & $2,439,861$ & $0.26 \%$ \\
\hline Distribution activities & & $8.67 \%$ \\
\hline Trade & $49,618,898$ & $5.23 \%$ \\
\hline Transportation & $32,640,042$ & $3.44 \%$ \\
\hline
\end{tabular}

\begin{tabular}{|c|c|c|}
\hline & $\begin{array}{l}\text { Production Value } \\
\text { (US } \$ 1,000)\end{array}$ & $\%$ \\
\hline Processed food products & & $8.19 \%$ \\
\hline Coffee products & $6,749,905$ & $0.71 \%$ \\
\hline Sugar & $4,388,781$ & $0.46 \%$ \\
\hline Rice products & $1,665,388$ & $0.18 \%$ \\
\hline Wheat flour & $2,258,098$ & $0.24 \%$ \\
\hline Vegetable oil mills & $9,275,711$ & $0.98 \%$ \\
\hline Other vegetables & $11,270,475$ & $1.19 \%$ \\
\hline Poultry products & $4,759,649$ & $0.50 \%$ \\
\hline Beef products & $5,716,668$ & $0.60 \%$ \\
\hline Other meat products & $5,614,827$ & $0.59 \%$ \\
\hline Dairy products & $6,261,652$ & $0.66 \%$ \\
\hline Animal feed & $4,356,302$ & $0.46 \%$ \\
\hline Other food products & $8,660,971$ & $0.91 \%$ \\
\hline Beverage & $6,763,839$ & $0.71 \%$ \\
\hline Other agriculture-related & & $1.06 \%$ \\
\hline Alcohol & $4,739,058$ & $0.50 \%$ \\
\hline Textiles & $5,347,674$ & $0.56 \%$ \\
\hline Other sectors & & $74.62 \%$ \\
\hline Resource oriented products & $16,056,473$ & $1.69 \%$ \\
\hline Other manufacturing & $354,002,945$ & $37.31 \%$ \\
\hline Services and government & $337,849,289$ & $35.61 \%$ \\
\hline All products & $948,712,411$ & $100 \%$ \\
\hline
\end{tabular}

The definition of farm types is based on two different data sets: the Agricultural Census of 1996/97 and the Pesquisa Padrão de Vida (PPV) of 1996 (Living Standard Survey), both from IBGE. The first source is more comprehensive and allows for more information across states, farm sizes, technology, etc. The second source provides more information on household characteristics, consumption structures, etc. Our definition of household types is be based on a study by the Ministry of Agrarian Reform/Incra and FAO, in which Brazilian farms were split into family and non-family based on size, use of hired labor, market orientation, income levels etc. Based on the objectives of this study, and on our analysis of characteristics of family and non-family farms, we have decided to work with four groups of family farms, and to deal with non-family farms as a group. Since consumption structures will come from different surveys, it is important to analyze the matching of those two in terms of general characteristics of farmers. Comparing the proportions of area, number of farms and number of people working in the different farm types, it can be seen that the distributions in the two data sets are quite similar. In other words, PPV consists of a good sample for the census results.

Different sectors present different linkages within the production system, be it through technical relationships with other sectors, or through income generation and distribution, and, hence, through consumption, as a feed-back mechanism. Therefore, it is important to take into consideration how wages and value added are distributed to different groups of income. As an example, from all wage income received by the lowest income group, farm sectors are responsible for $20 \%$, increasing to $24 \%$ in the next decile, and decreasing there on. For rich people, wages coming from farm producing sectors are less 
important. The participation of different income groups in food manufacturing sectors is quite different, with the very poor receiving a smaller portion of income from these sectors. This contrast in the two types of sectors producing food products illustrates the need to consider how different sectors can influence income distribution. It is also clear from the data that food directed to the consumption of the local population are more important in the income generation of poor people, both in terms of wages and value added. Soybean production is more important for employees and producers in the middle-income range. Therefore, a price shock in this sector tends to affect this group of households more intensively than poor households, at least in the first round of effects.

Since income is distributed differently across sectors, households associated to each sector are expected to have a different consumption structure. This is especially true when considering the differences in consumption between urban and rural families. Therefore, an important step towards constructing a SAM is the consideration of how families spend their income. The data sources for this part of the study are the 1987 and 1995/96 Household Expenditure Surveys developed by IBGE. For urban households, we use the household surveys of 1987 and 1995/96 (POF); we consider 4 groups of households, defined according to income levels. For rural households, we use the 1996 PPV. The five categories of farms presented before will be considered. Thus, we have consumption structures for 10 types of consumers, 6 rural (5 farmers, 1 employees), and 4 urban. The data show that poorer households spend a higher proportion of their income on agricultural raw food. As expected, rural households present more self-consumption than urban households, and the proportion decreases from family farms 1 through 4; urban households spend a larger share of their income with housing. In general, both housing and education expenditure shares rise from low-income households to high-income ones.

\subsection{Demand Elasticities}

A pseudo panel was constructed to calculate own-price, cross-price and income elasticities for a disaggregated list of food products, as well as for aggregated groups of non-food products. A two-stage demand function model commonly used in agricultural studies was constructed, with a more sophisticated estimation procedure. Household expenditure data were used to construct a three-dimension pseudo panel with: time, region and income bracket. This procedure allows for the control for effects that vary with time, but are constant across regions (random effects), as well as for effects fixed in time, but which vary across regions (fixed effects), effects which, when not specified, are included in the omitted variables, biasing the parameter estimators.

Data used came from the 1987/88 and 1995/96 POF - Pesquisa de Orçamentos Familiares, household expenditure surveys produced by IBGE, the Brazilian official statistics office. They consist of surveys covering expenditure of 14,000 families in 1987/88 and 16,000 families in 1995/96, for the most important metropolitan areas in Brazil: Belém (North), Fortaleza, Recife and Salvador (Northeast), Belo Horizonte, Rio de Janeiro and São Paulo (Southeast), Curitiba and Porto Alegre (South), and Brasília (Center-West). Only families with some expenditure with some of those items were included in the study, resulting in samples of 404.366 observations in 1987/88 and 347,569 in 1995/96. The product groups are as follows: home maintenance - cleaning items, such as soap, detergents, etc.; accessories - bags, belts, wallets and bijouterie; transportation urban bus, fuel and labor; personal care - shampoo, soap, toilet paper etc.; personal 
expenditure - maids, hairdresser and sewing professionals; recreation - movies, clubs, magazines and non-academic books; and education - tuition for elementary and high schools, books and stationery.

\section{Policy Simulations}

Given the framework presented above, it is expected that trade liberalization will change the international prices of agricultural commodities, with effects on rural and urban families in Brazil. Since different types of rural and urban households are involved in the productive process in different ways, it is expected that the international price changes will affect them differently. The aim of this chapter is to present the expected impacts for the different household types, hence on inequality and poverty.

\subsection{Expected changes in international commodity prices}

The international and domestic changes in product prices are exogenous to this study. They were calculated independently using a Computable General Equilibrium model (CGE) of the world economy, in which the flow of trade between countries is considered. This world model is used to simulate a situation in which all forms of subsidies are reduced by half in every country (including Brazil, whenever it is the case). The estimated expected price changes are displayed in Table 3.1, which presents the impacts on the domestic prices, export prices, import prices, and export volume. All food products exported by Brazil are expected to experience domestic price increases of over $2 \%$, with a maximum of $5.68 \%$. 
Table 3.1 - GTAP expected changes in prices and export volumes (\%)

\begin{tabular}{lcccc}
\hline \multicolumn{1}{c}{ GTAP Products } & Domestic Prices & Export Prices & Import Prices & Export volume \\
\hline Paddy rice & 2.62 & 3.24 & 0.45 & 94.52 \\
Horticulture & 2.44 & 3.24 & 0.59 & -6.52 \\
Sugar cane \& beet & 2.52 & 0,00 & -14.24 & -69.51 \\
Plant fibres and other crops & 2.76 & 3.39 & 0.14 & -3.94 \\
Wheat & 1.64 & 2.41 & 1.14 & -11.53 \\
Coarse grains & 2.95 & 3.6 & 0.85 & 0.26 \\
Oilseeds & 2.43 & 3.18 & 1.28 & 1.21 \\
Bovine cattle, sheeps & 5.68 & 6.34 & 1.81 & -6.35 \\
Raw milk & 3.16 & 3.76 & 1.98 & -31.43 \\
Non-ruminants & 3.88 & 4.56 & 0.82 & -8.4 \\
Dairy & 3.03 & 3.03 & 3.10 & 17.31 \\
Sugar & 2.01 & 2.01 & 1.57 & 7.24 \\
Bovine meat & 3.96 & 3.96 & 1.44 & 163.85 \\
Pig\&Poultry meat & 3.99 & 3.99 & 1.27 & 1.29 \\
Other processed food & 2.3 & 2.3 & -0.77 & 3.28 \\
Manfuactures & -0.03 & -0.03 & -0.13 & 7.22 \\
Textiles, wearing apparel, leather & 0.02 & 0.02 & -0.48 & -0.04 \\
Services & 0.99 & 0.99 & 0.10 & -2.15
\end{tabular}

\subsection{Aggregate impacts on the Brazilian economy}

Aggregate results are presented in Table 3.1. As a consequence of increases in prices and export volumes, real aggregate GDP is expected to grow by $1.6 \%$, real household income by $1.58 \%$, and employment level by $1.41 \%$. These are quite low values, reflecting the fact that Brazilian economy is highly diversified, with agricultural activities and food processing industries taking a small share of total activity. Besides that, exports are a small share of total production. For raw agricultural products, it represented only 3\% of total production in 1999. Within this group, soybeans presented the largest export share, $31.1 \%$, in spite of the importance of the Brazilian production in the international market. For processed food products as a group, the export share was $13.6 \%$, with the largest shares belonging to sugar (35.6\%), and coffee products (32.1\%). The importance of the domestic market explains the low impacts of the simulated export increases, and also the fact that all types of families end-up receiving the benefits of increased exports, as will be shown later on in this chapter.

Table 3.2 - Aggregate results

\begin{tabular}{lc} 
& $\%$ \\
\hline Real GDP & 1.60161 \\
Real Household Income & 1.57591 \\
Consumer Price Index & 1.63406 \\
GDP Deflator & 1.27965 \\
Employment & 1.40686 \\
\hline
\end{tabular}




\subsection{Global results sensitivity to input limitation parameters}

The model estimates Leontief-type price multipliers that spread the effects of input price increases throughout the economic system. These price increases affect real income and hence domestic demand. Since their estimation was made without the sophisticated econometric techniques applied to demand elasticities, it is important to check whether or not results are sensitive to their values. For that, the parameters were changed, with the resulting changes in real GDP, real household income, consumer price index, general domestic price deflator, and employment are show in table 3.3.

It can be seen that the model results are not sensitive to these parameters, since the differences are all small. For example, if both parameters are set to their lowest level, implying less price sensitivity of input supply, real DGP growth would go up by 0.00029 percentage points (from 1.60161\% to $1.60132 \%$ ). Since the price transmission mechanism is linear, a similar increase in the parameter values will produce the same quantitative results, only in the other direction. The largest impacts are on employment: from $1.40686 \%$ to $1.40578 \%$, a change of 0.00108 percentage points, still negligible. Therefore, there is no basis to suspect that the aggregate results presented would change significantly if different limitations on the input side were imposed to the model.

Table 3.3 - Sensitivity of aggregate results to changes in input limitation parameters

\begin{tabular}{lccccccc}
\hline Parameter values & Model & (a) & (b) & (c) & (d) & (e) & (f) \\
Manufactured inputs & 0.4 & 0.2 & 0.6 & 0.4 & 0.4 & 0.2 & 0.6 \\
Land & 0.5 & 0.5 & 0.5 & 0.3 & 0.7 & 0.3 & 0.7 \\
Labor & 0 & 0 & 0 & 0 & 0 & 0 & 0
\end{tabular}

Results (\% changes)

$\begin{array}{llllllll}\text { Real GDP } & 1.60161 & 1.60173 & 1.60149 & 1.60177 & 1.60144 & 1.60189 & 1.60132 \\ \text { Real Household Income } & 1.57591 & 1.57608 & 1.57574 & 1.57614 & 1.57568 & 1.57631 & 1.57551 \\ \text { CPI } & 1.63406 & 1.63406 & 1.63406 & 1.63406 & 1.63406 & 1.63406 & 1.63406 \\ \text { GDP Deflator } & 1.27965 & 1.27965 & 1.27965 & 1.27965 & 1.27965 & 1.27965 & 1.27965 \\ \text { Employment } & 1.40686 & 1.40637 & 1.40735 & 1.40627 & 1.40745 & 1.40578 & 1.40794\end{array}$

Changes in results

$\begin{array}{lrrrrrrr}\text { Real GDP } & - & 0.00012 & -0.00012 & 0.00017 & -0.00017 & 0.00029 & -0.00029 \\ \text { Real Household Income } & - & 0.00017 & -0.00017 & 0.00023 & -0.00023 & 0.00040 & -0.00040 \\ \text { CPI } & - & 0.00000 & 0.00000 & 0.00000 & 0.00000 & 0.00000 & 0.00000 \\ \text { GDP Deflator } & - & 0.00000 & 0.00000 & 0.00000 & 0.00000 & 0.00000 & 0.00000 \\ \text { Employment } & - & -0.00049 & 0.00049 & -0.00059 & 0.00059 & -0.00108 & 0.00108\end{array}$




\subsection{Global results sensitivity to the allocation of additional exports to farm types}

The results on Table 3.2 consider that additional exports will be allocated to the five farm types proportionally to their previous shares in production. One might argue that these extra exports are probably to be served by large producers, since they are the ones more entrepreneurial and market-oriented, and that this could lead to different results in comparison to the ones presented. Thus, in this section simulations were made considering different allocation of exports across farm types. In Table 5.4 three situations are portrayed. In the first, the increased international demand is to be served by all types of farmers, proportionally to their participation in production. The second considers that only farmers of types 4 and 5 (large family and commercial farmers) will export and provide inputs to exporting sectors (for example, only large producers will provide sugar cane as inputs to the manufacturing of sugar). The third situation considers that only the three first types of family farmers will sell abroad and provide inputs to food processing activities.

It will be shown in a later section that these three situations will produce differences in distributive effects, but at the aggregate level, the impacts are really small, as the results displayed in Table 5.4 indicate. This is explained by the important role of domestic demand originated in the urban sector of the Brazilian economy. As presented in Chapter 2 , the share of urban population is around $80 \%$, and the share of urban income is around $90 \%$. Thus, an increase in the exports of agricultural goods will end-up affecting the income of urban households, which in turn will purchase agricultural products from all types of farms. Thus, these results indicate that the results are quite robust to different allocation of exports to farm types.

Table 3.4 - Sensitivity of global results to different export profiles

\begin{tabular}{lcc}
\multicolumn{1}{c}{$\begin{array}{c}\text { Allocation of } \\
\text { additional exports }\end{array}$} & $\begin{array}{c}\text { Change in aggregate } \\
\text { Household Income }\end{array}$ & $\begin{array}{c}\text { Difference } \\
\text { (\% points) }\end{array}$ \\
\hline Proportional to shares in production & $1.5759 \%$ & - \\
Large family and commercial farms only & $1.5713 \%$ & 0.0046 \\
Small family farms only & $1.5694 \%$ & 0.0065 \\
\hline
\end{tabular}

\subsection{Distributive aspects}

In this section the impacts are analyzed considering their different effects across household types. The aggregate results presented before are detailed as they accrue to different households, and some synthetic indicators are used to consider the impacts on poverty and inequality. 


\subsubsection{Effects across household types}

Table 3.5 shows the expected changes in income received by households resulting from the GTAP scenario of domestic price changes derived from international adjustments. It shows that agricultural employees and commercial farmers are the ones expected to have the largest positive impacts $(+2.95 \%$ and $+2.84 \%)$. In general, rural households will benefit more than urban households. The two poorest rural household types will receive the lowest positive impacts among rural households $(+1.91 \%)$, but this is larger than the best case of urban households $(+1.49 \%)$. The best case within agricultural farmers is a positive impact of $2.11 \%$ (type $\mathrm{D}$ ), still 0.8 percentage point below commercial farmers.

Table 3.5 - Impacts on household income across family types

\begin{tabular}{|l|c|}
\hline \multicolumn{1}{|c|}{ Family type } & $\begin{array}{c}\text { Household } \\
\text { Income growth (\%) }\end{array}$ \\
\hline & \\
\hline Family Agriculture 1 & 1.9066 \\
\hline Family Agriculture 2 & 1.9217 \\
\hline Family Agriculture 3 & 2.0576 \\
\hline Family Agriculture 4 & 2.1130 \\
\hline Commercial Farmers & 2.8458 \\
\hline Agricultural Employees & 2.9522 \\
\hline Urban 1 & 1.4564 \\
\hline Urban 2 & 1.4830 \\
\hline Urban 3 & 1.4871 \\
\hline Urban 4 & 1.4785 \\
\hline & \\
\hline All Households & $\mathbf{1 . 5 7 5 9}$ \\
\hline
\end{tabular}

Table 3.6 illustrates the various stages in the estimation of the model, as presented in section 4. Column $\mathrm{F}$ is exactly the same as in Table 3.5, exhibiting the final effects. Column $\mathrm{E}$ indicates the effects on income of increased exported volumes, without considering any price changes. All changes are positive, for it shows the effects on the economy of increasing the production of the respective sectors, at the previous price levels (except for input price changes, displayed in the column D). Comparing these two columns, it is clear that rural households increase their numbers when going from $\mathrm{E}$ to $\mathrm{F}$, and urban households present decreasing values. This is expected, for urban households face more negative price impacts, given their consumption baskets and income sources.

Column A presents income changes due to increased product prices, and column B shows income compensation, that is, income that was distributed to other household types in order to keep total income constant in the system. The sum of these two columns results in positive numbers for rural households, and negative for urban families, indicating a net transfer of income from urban to rural sectors due to an overall increase in the price of agricultural goods (all price-inelastic). Thus, while all households benefit from increased exports, rural families receive positive effects of price and income compensation, while 
urban families have to face increased agricultural prices. Column C displays the effects on income of input price restrictions (land and manufactured inputs), and column D introduces the income compensation for the resulting price changes.

Table 6.6 - Changes in household income, by estimation stage

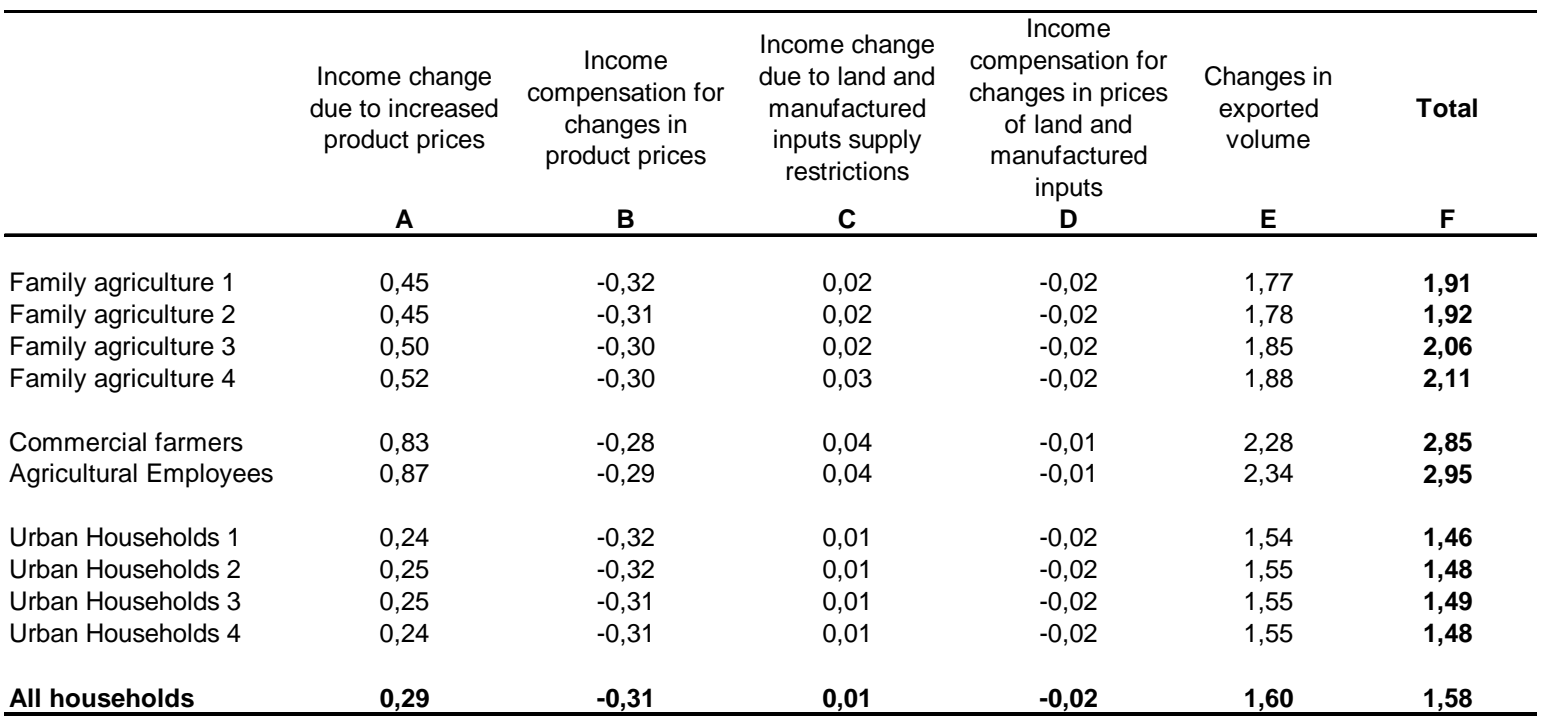

\subsubsection{Sensitivity to different allocations of additional exports}

Even if the largest impacts accrue to commercial farmers and large family farmers, it is observed that all family farm types receive positive effects. As mentioned in section 3.4 , this is related to the share of demand originated in the urban sector of the Brazilian economy, implying that any increase in exports will affect urban households, which in turn will purchase agricultural products from all types of farms. Adding to that, the GTAP simulation forecasts an increase in manufacturing exports, which is much larger, in size, than the increased value of food products exports. In order to illustrate that, the final effect was decomposed into the direct effect, and the total effect (direct, indirect, induced, and price effects). In the first step, only the direct impact of the increased export values are considered, ignoring the indirect (purchases of inputs from other sectors) and induced (consumer purchases) by the initial impact. In the second step, these indirect and induced effects are included, as well as the effects of domestic prices on real income all over the economy.

The same two extreme cases commented on Section 5.4, referring to different allocations of additional exports across farm types, are considered here. The first considers that only household types 4 and 5, that is, large family and commercial farmers will produce the additional exports, both of final products and agricultural inputs to export sectors. The second allocates all additional exports to small family farmers. Table 5.7 
presents the results of the standard run, and the two extreme cases. The global changes were already discussed in Section 5.4, and are very small, but the changes to specific household types are now important. Family farmers of type 1 (small) can get income changes varying from $1.45 \%$ to $3.15 \%$, with a standard run scenario of $1.91 \%$; commercial farmers' income changes vary between $1.6 \%$ and $3.08 \%$, with a standard run value of $2.84 \%$. These scenarios practically do not affect income growth for urban households.

Table 3.7 - Impacts on household income growth of different allocations of additional exports (Changes in household income, \%)

\begin{tabular}{|c|c|c|c|c|c|c|c|c|}
\hline & Stanc & d run & & e farms & & & all farms & \\
\hline & Direct & Total & Direct & Total & Difference & Direct & Total & Difference \\
\hline Family Agriculture 1 & 0.3706 & 1.9066 & 0.0 & 1.4551 & -0.4515 & 1.4497 & 3.1501 & 1.2436 \\
\hline Family Agriculture 2 & 0.3969 & 1.9217 & 0.0 & 1.4517 & -0.4701 & 1.4733 & 3.1582 & 1.2364 \\
\hline Family Agriculture 3 & 0.4509 & 2.0576 & 0.0 & 1.5395 & -0.5182 & 1.8796 & 3.6984 & 1.6407 \\
\hline Family Agriculture 4 & 0.4659 & 2.1130 & 0.6105 & 2.2493 & 0.1363 & 0.0 & 1.6045 & -0.5085 \\
\hline Commercial Farmers & 0.7592 & 2.8458 & 1.0214 & 3.0881 & 0.2424 & 0.0 & 2.1179 & -0.7279 \\
\hline Agricultural Employees & 0.8148 & 2.9522 & 0.9341 & 3.0752 & 0.1230 & 0.0 & 1.9570 & -0.9951 \\
\hline Urban Family 1 & 0.2374 & 1.4564 & 0.2389 & 1.4578 & 0.0014 & 0.2381 & 1.4479 & -0.0085 \\
\hline Urban Family 2 & 0.2643 & 1.4830 & 0.2657 & 1.4838 & 0.0008 & 0.2649 & 1.4752 & -0.0078 \\
\hline Urban Family 3 & 0.2674 & 1.4871 & 0.2688 & 1.4878 & 0.0007 & 0.2680 & 1.4794 & -0.0076 \\
\hline Urban Family 4 & 0.2638 & 1.4785 & 0.2659 & 1.4806 & 0.0021 & 0.2648 & 1.4709 & -0.0076 \\
\hline All households & 0.2970 & 1.5759 & 0.2956 & 1.5713 & -0.0046 & 0.2963 & 1.5694 & -0.0065 \\
\hline
\end{tabular}

These simulations illustrate the point already made in Section 3.4, on the importance of domestic demand. Considering the case in which only large farms can export, it can be seen that the direct impacts on the first three categories of family farmers is null. However, the indirect and induced effects coming from the increased activity in the economy at large imply income increases for these households of over $1.45 \%$. In the standard run case, the total effect for these three family groups is over $1.91 \%$, from a direct effect between $0.37 \%$ and $0.45 \%$ only. Given the small farmers minor share in production, the allocation of extra exports to them produces large increases in their growth rates. This indicates that the distributive effects will differ between the cases. These changes in distributive impacts are displayed in table 3.1, in which the same synthetic inequality and poverty indicators shown in Table 3.7 are presented. 
Figure 3.1 - Impacts of exports allocation

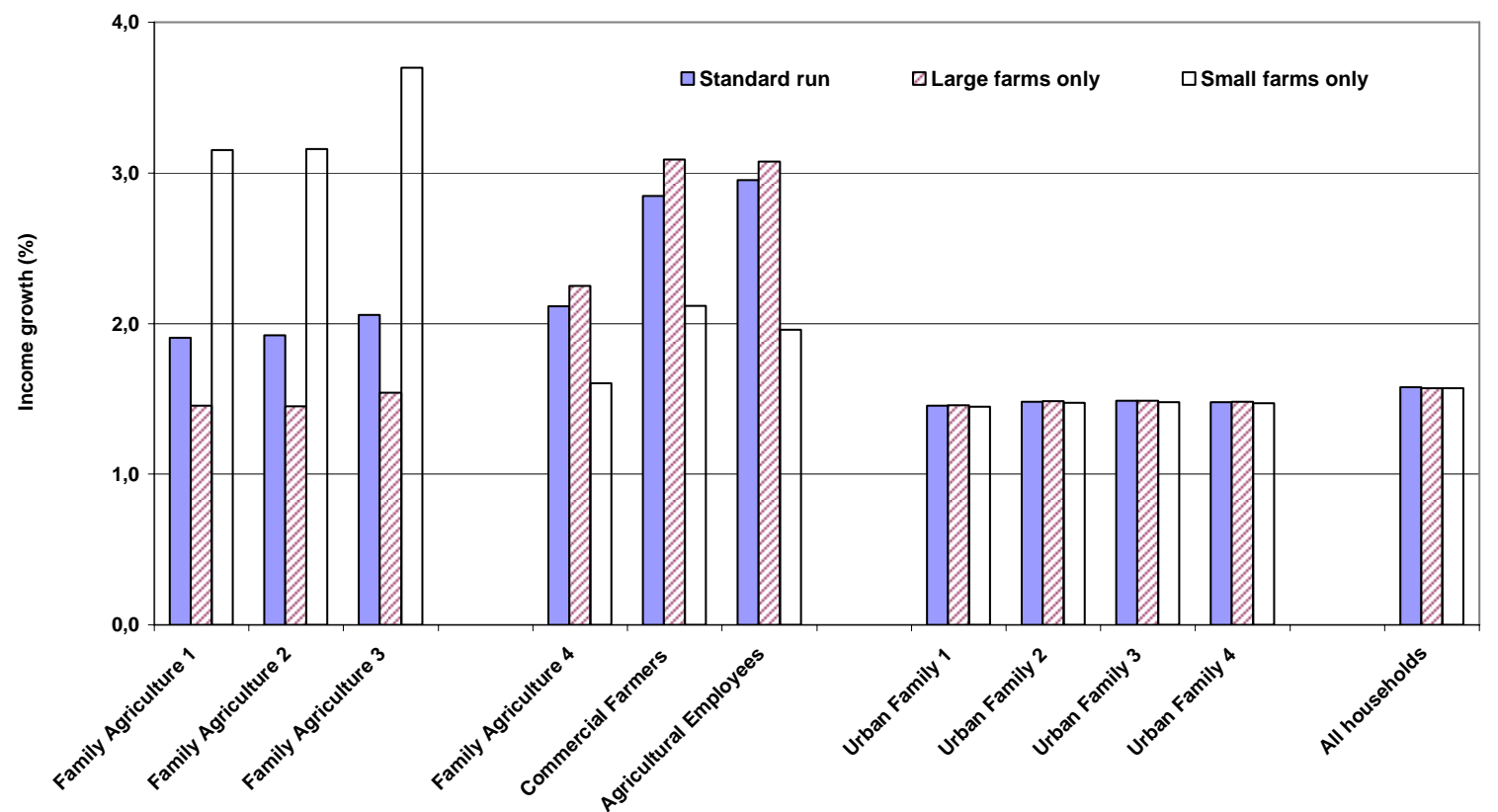

\subsubsection{Impacts on poverty and inequality}

In this section the impacts of the changes simulated in the model are considered with the use of synthetic indicators of poverty and inequality. Income inequality is portrayed through Gini and Theil coefficients, which are calculated for the whole income distribution, and separately for urban, rural, and family agricultural households. As for poverty indicators, changes in the percentage of indigents and in the number of poor people are considered. For this, households from PNAD 2003 were allocated to the same ten categories employed in this study and the additional income coming from the simulations were summed to their previous incomes ${ }^{2}$. Since impacts are differentiated across household types, the aggregate income distribution changes, leading to new Gini and Theil coefficients.

Results are presented in Table 3.8, in which column A presents the basic case, referring to the situation present in the SAM. Column B shows the impacts on income distribution of the standard run of the model (additional exports proportional to previous shares in production). It can be seen that the price changes simulated in the standard run of this model leads to a marginal reduction in the general Gini index, from 0.58735 to 0.58708. Inequality within urban households is practically unchanged, and inequality within rural households, and even within family agriculture households, increases marginally. As expected, if additional exports are sold by large family and commercial farmers only (column C), Gini and Theil coefficients are reduced by less than in the

\footnotetext{
${ }^{2}$ The necessary correction for price changes between 1999 and 2003 was applied.
} 
previous case, and inequality within rural families increases more than before, although still marginally. Finally, if only small farms export the additional products purchased by foreign demand, income inequality is reduced in the rural area, although still only slightly. Similar results are achieved with the Theil index.

The bottom part of Table 3.8 presents headcounts of population in extreme poverty, that is, people that do not receive income to buy food compatible with a minimum diet of calories and proteins ${ }^{3}$. State-specific conservative poverty lines were used, meaning that the number of poor is smaller than if other poverty lines available were used ${ }^{4}$. Therefore, the impacts on the number of poor presented here are to be taken as maximum values. Again, results are very modest, for a number between 334,000 and 427,000 people would be taken away from extreme poverty, representing changes between $2.98 \%$ and $3.81 \%$ of the total number of people in that situation. There is an important regional aspect here, for in the Northeast region changes will be much larger (between $4.75 \%$ and $6.19 \%$ ), with over $75 \%$ of people moving away from extreme poverty coming from this region.

These minor impacts on income inequality and poverty are expected, given the small aggregate effects on GDP, household income and employment, and the large share of the urban economy in Brazil. Since most changes only affect rural households, and these are only a small part of Brazilian population, these changes end-up presenting only small impacts on aggregate income distribution.

Table 3.8 - Effects of different export scenarios on poverty and distribution

\begin{tabular}{|c|c|c|c|c|c|c|c|}
\hline & \multirow[b]{2}{*}{ Basic case } & \multicolumn{3}{|c|}{ Export scenarios } & \multirow[b]{3}{*}{$(B-A)$} & \multirow[b]{2}{*}{ Changes } & \multirow[b]{3}{*}{$(D-A)$} \\
\hline & & $\begin{array}{l}\text { Proportional to } \\
\text { share in }\end{array}$ & $\begin{array}{l}\text { Large family } \\
\text { and commercial }\end{array}$ & $\begin{array}{l}\text { Small family } \\
\text { farms only }\end{array}$ & & & \\
\hline & A & $\mathrm{B}$ & $\mathrm{C}$ & $\mathrm{D}$ & & $(C-A)$ & \\
\hline \multicolumn{8}{|l|}{ Gini Index } \\
\hline Geral & 0,58735 & 0,58708 & 0,58721 & 0,58680 & $-0,00027$ & $-0,00014$ & $-0,00055$ \\
\hline Urban & 0,56912 & 0,56913 & 0,56913 & 0,56913 & 0,00001 & 0,00001 & 0,00001 \\
\hline Rural & 0,54465 & 0,54515 & 0,54594 & 0,54309 & 0,00050 & 0,00129 & $-0,00156$ \\
\hline Family agriculture & 0,50357 & 0,50392 & 0,50491 & 0,50105 & 0,00035 & 0,00134 & $-0,00252$ \\
\hline \multicolumn{8}{|l|}{ T - Theil Index } \\
\hline Geral & 0,70498 & 0,70440 & 0,70468 & 0,70383 & $-0,00058$ & $-0,00030$ & $-0,00115$ \\
\hline Urban & 0,65291 & 0,65291 & 0,65291 & 0,65291 & 0,00000 & 0,00000 & 0,00000 \\
\hline Rural & 0,66532 & 0,66708 & 0,66932 & 0,66130 & 0,00176 & 0,00400 & $-0,00402$ \\
\hline Family agriculture & 0,48364 & 0,48431 & 0,48663 & 0,47743 & 0,00067 & 0,00299 & $-0,00621$ \\
\hline \multicolumn{8}{|c|}{ Population in extreme poverty } \\
\hline Number & 11.187 .966 & 10.827 .744 & 10.854 .230 & 10.761.177 & -360.222 & -333.736 & -426.789 \\
\hline Share & $6,68 \%$ & $6,46 \%$ & $6,48 \%$ & $6,42 \%$ & $-0,22 \%$ & $-0,20 \%$ & $-0,25 \%$ \\
\hline Percentage change & & & & & $-3,22 \%$ & $-2,98 \%$ & $-3,81 \%$ \\
\hline
\end{tabular}

\footnotetext{
3 Taken from Rocha, S. and Albuquerque, R. C. "Geografia da pobreza extrema e vulnerabilidade à fome”, Seminário Especial Fome e Pobreza - Fórum Nacional, Rio de Janeiro, Set 2003 (www.forumnacional.org.br/publi/ep/EP0054.pdf)

${ }^{4}$ For a discussion, see Takagy, M., Grazziano da Silva, J. and Del Grossi, M. "Pobreza e fome: em busca de uma metodologia para quantificação do problema no Brasil, Campinas IE/UNICAMP, Texto para Discussão N. 101, Jul 2001, and Silveira, F. G. et. all. "Insuficiência alimentar nas grandes regiões urbanas brasileiras: estimativas a partir da POF 1995/96-IBGE” Economia Aplicada, Vol. 8, N. 3, Jul 2003
} 


\section{Concluding remarks}

By including different farm types, their differentiated products mix, their received income, and their consumption structure, it is possible to estimate how changes in specific prices will affect income distribution within the rural sector. Considering the urban sector, it is also possible to estimate how different groups of urban households will be affected by the price changes, given their income sources and consumption structures. As a result, after any price change in the system, the model will provide a new picture of the income distribution in the country. This information is very important for assessing the consequences of trade liberalization, for example, for in that case international prices will tend to change, with consequences for inequality and poverty in developing countries. Given the estimated impacts on different groups of producers and consumers, different sorts of cushioning policies can be designed.

\section{References}

Guilhoto, J.J.M., P.H.Z. da Conceição, e F.C. Crocomo (1996). "Estrutura de Produção, Consumo, e Distribuição de Renda na Economia Brasileira: 1975 e 1980 Comparados”. Economia \& Empresa. 3(3):1-126.

Guilhoto, J.J.M., U.A. Sesso Filho (2004). "Estimação da Matriz Insumo-Produto à Partir de Dados Preliminares das Contas Nacionais”. Economia Aplicada. In Printing.

Fonseca, M.A.R., e J. J. M. Guilhoto (1987). "Uma Análise dos Efeitos Econômicos de Estratégias Setoriais". Revista Brasileira de Economia. Vol. 41. N. 1. Jan-Mar. pp. 81-98.

Olivette, M. P. A., Caser, D. V. and Camargo, A. M. M. P. (2002) “Distribuição da Área Agrícola: as grandes regiões do Brasil na década de 90”, Agricultura em São Paulo, 49(1):95-125

Gasquez, J. G., Rezende, G. C., Villa-Verde, C. M., Conceição, J. C. P. R., Carvalho, J. C. S. and Salerno, M. S. (2003) "Desempenho e crescimento do agronegócio no Brasil” mimeo, IPEA 